\title{
SUSTAINABILITY AND SOCIALISM: SOCIO-ECOLOGICAL IDEAS IN THE URBANIZATION OF NEW BELGRADE
}

UDC 711.4:502.131.1(497.11)

\section{Jelena Ristić Trajković ${ }^{1}$, Danica Stojiljković}

${ }^{1}$ University of Belgrade, Faculty of Architecture, Belgrade, Serbia

${ }^{2}$ University of Belgrade, Institute for Multidisciplinary Research, Belgrade, Serbia

\begin{abstract}
The main objective of this research is to explore the ecology ideas in socialism, or more precisely socio-ecological ideas that were present in urbanization of New Belgrade. The paper investigates beginnings of the development of environmental consciousness that emerged in late sixties of the twentieth century due to rapid urbanization processes of Belgrade, but also draws attention to specific architectural and urban concepts in historical urban development of New Belgrade which are from the standpoint of modern principles of sustainability positive examples of social - environmental exchanges. What can we learn from past experiences? Since the power relations of socio-environmental conditions that shape urban environment are constantly changing in terms of scale and participants in the process of urbanization, historical and geographical insight into the constantly changing urban configuration is necessary for understanding and consideration of future radical political-ecological urban strategies.
\end{abstract}

Key words: ecology, socialism, sustainable urban development, socio-environmental change, New Belgrade

\section{INTRODUCTION}

We live in the world chained by the term 'ecology'. It is one of the most frequent words nowadays and it is impossible to avoid it even in every-day conversation. Everybody talks about ecology, threatens by it or swears by it. It is simultaneously used as the measure for the worth of the present and as the foothold tor the future. [1]

Received March 28, 2016 / Accepted June 30, 2016

Corresponding author: Jelena Ristić Trajković

University of Belgrade, Faculty of Architecture, 11000 Belgrade, Bulevar kralja Aleksandra 73/II, Serbia

E-mail: arch.jelena.ristic@gmail.com 
The sustainable development and environmental protection issues, as well as the problems of resource and biotechnological restrictions of the city growth are some of the numerous urban topics that have become relevant or even crucial for the existence and future of every large city. Due to the spatial, demographic, geopolitical, political or proprietary changes, both the spatial and functional transformation of the cities was intensified in the second half of the $20^{\text {th }}$ century. Since physical space belongs to the category of limited and non-renewable resources, the consequences of uncontrolled consumption of space are obvious both in the city centre and in the suburban areas. The consequences of such transformation are more demanding conditions for the environmental protection. Owing to the exploitation of the non-renewable energy sources and pollution of the environment there are growing number of researches in the field of sustainable development.

Today, when we talk about jeopardized environment, it is obvious that it is a subject broached a long time ago. Ever since man accepted the fact that "the industrial" became the dominant characteristic of our civilization, the interest and concern for its consequences have simultaneously begun to grow. Although followed by a socio-economical development, the urbanization of nature has also become a generator of a series of critical conditions in every segment of both spiritual and material relations. However, in the increasingly diverse and extensive literature on sustainable development, little attention has been devoted to the urban as the process created by socio-environmental change. The aim of this research is to gain insight into the questions of ecology and sustainability in socialism, or more precisely socio-ecological ideas in urbanization of New Belgrade. Paper investigates beginnings of the development of environmental consciousness that emerged in late sixties of the twentieth century due to rapid urbanization processes of Belgrade, but also draws attention to specific architectural and urban concepts in historical urban development of New Belgrade which are from the standpoint of modern principles of sustainability positive examples of social - environmental exchanges.

Following the ideas of urban development during the twentieth century, it can be seen that due to the global process of urbanization and industrialization ideas and concepts based on ecological approach to design and planning increased in frequency. Relevance of the research is primarily reflected in the necessity of solving the numerous problems of the modern city, primarily non-ecological structure of the urban area and lack of environmental awareness, both by experts, and users. The work argues that rational operation at present can only be achieved through understanding processes and situations in the history of the city, and that accordingly serious research on the future development must be based on a historical approach.

\section{THE PROCESS OF SOCIO-ENVIRONMENTAL EXCHANGE}

Both ecologically oriented social theoreticians and socially oriented environmental theoreticians have considered the relationship between the city and nature as an interesting research topic. Urbanization was long considered as a process where "natural" environment is being replaced by "built" environment. Such approach positions the city as the antithesis to nature. During the last couple of decades, theorization of the mannature relationship has been considerably improved. Contemporary scientists more and 
more recognize that both natural and ecological conditions and processes cannot exist apart from the social processes, but also that the existing social and natural conditions are always the result of a complex transformation of the existing configurations that are at the same time natural and social.

Friedrich Engels was the first to point out the complexities of socio-environmental relationships. He maintains that by perceiving the nature as a whole we can see the picture of a continuous network of relations and interactions, permutations and combinations, where nothing remains where it was, but keeps moving, changing and vanishing [2]. Furthermore, the idea of 'metabolism' is the central metaphor of the Marx's approach to the analysis of the internal dynamic relations between man and nature. According to Marx, the socionatural metabolism provides the basis and possibility for the existence of socio-environmental history throughout which both nature and man transform. It can therefore be concluded that the materialistic approach insists on "nature" being an integral part of the social life metabolism.

Following this way of understanding the socio-environmental relationships Henri Lefebvre, a representative of the neo-Marxist thought, claimed that natural space had never really stopped to be the origin of the social process. Social production of urban environments Lefebvre calls "the second nature". According to him social production is necessarily socially generated thus opening the way to understanding the complex mixture of political, economic and social processes that shape and reshape the urban landscapes. Both Lefebvre and the rest of neo-Marxists, including David Harvey, considered the urban to implicitly represent the major achievement of the capitalistic (or "modern") social relations and the broader global, socio-environmental relations whereby the modern life has been created, both materially and culturally.

Within the capitalistic social relationships, permeated by the circulation of capital and mobilization of human resources, the inevitable metabolic transformations and synthetic relations between society and nature occurred. It is therefore important to understand the gradual quality of the capital accumulation functioning through the ecosystem processes (systemic ecology processes) from the ecology viewpoint. Energy flows, raw material balance changes and environmental transformations (some of them irreversible) depict the levels and influences of the metabolic transformations on the ecosystem. Likewise, Harvey in his book Juistice, Nature and the Geography of Difference claims that there is nothing unnatural about New York:

The circulation of money and of capital have to be construed as ecological variables every bit as important as the circulation of air and water. [3]

However, theorists in Yugoslavia recognize a significant difference in terms of the position of ecology in socialism, in relation to position of ecology in capitalism. Accordingly in 1973, in the journal "Čovjek i prostor (Man and Space)" Keller writes about the relationship between socialism and ecology. He points out that for many consideration of the relationship of ecology and socialism as a model of socio-political system seems incompatible at a first glance, while to others it sounds like dogmatic phrase. However, comparison of the characteristics of the socialist and capitalist social organization yields a conclusion that capitalism because of its determination "is not able to solve any environmental problem." Therefore, "exactly in terms of environment lies a big opportunity of socialism" [4]. 
If efforts are focused on creating the kind of environmental to be a decent place for life and work of the man, which will fully express the aspirations, capabilities, and knowledge of man, socialism may have the strength to overcome these problems. Understandably, this assumes that the creation of a new system of socialist cultural and ethical values incorporates in it a new attitude towards our environment [4].

\section{ECOLOGY AND SOCIALISM}

In the seventies of the last century, there was a pronounced need and awareness of importance of environment preservation, particularly natural. Theses on affirmative acceptance of the environmental design as "a basic life activity" became current, both in architectural practice, as well as at conferences and in the literature.

The importance of ecology in designing disciplines was emphasized within the professional community, but also it was emphasized by the fact that the process of direct involvement of ecology in planning process is very slow due to inadequate knowledge of environmental problems, academic attitudes on ecological communities and the distrust of design disciplines in "what ecologist can or cannot do." The triple role of ecology was emphasized: management of natural areas, ecological design and education in the context of ecology. [5] Also, there were actual topics of inclusion of ecological components in the process of design and planning, place of ecology and environment in the integrated planning and management of socio-economic development, evaluation of environmental characteristics, as well as methods for the inclusion of environmental aspects in planning and design process [6].

When we speak about the beginnings of ecological thoughts in our country, Janković in his book "Development of ecological thought in Serbia" points out that our region very quickly and without major dilemma accepted and developed precisely the most progressive ecological ideas of the most developed European understanding. Therefore, he concludes that the original contribution of our scholars in the development of environmental thought in the theory of European ecology was not insignificant, but primarily points out reasonably and profound acceptance of what is in modern ecology was the best and most advanced [7].

During the seventies in Yugoslavia occurred major problems in protecting natural environment primarily as a result of the development of the market economy. In a market economy, the nature is value that can be exploited limitlessly and without consequences. For this reason, during this period, numerous initiatives and scientific works started in order to preserve and protect the environment. According to the records of the Union of Engineers and Technicians of Yugoslavia in the period from 1968 to 1975 more than eighty important meetings on the protection and improvement of environment were held. ${ }^{1}$

\footnotetext{
${ }^{1}$ Among the most important international conferences were: "Science and Society" in Herceg Novi; "Congress on Waters of Yugoslavia" - Belgrade 1969; Scientific Conference in SANU "The man and the environment" Belgrade 1973; Forest as factor of protection and improvement of the environment - Belgrade 1974, Zagreb 1975; First Yugoslav Conference on fight against noise - Belgrade 1974; The first conference of the Adriatic cities of Yugoslavia and Italy on the protection of the Adriatic - Split 1975; Meeting of the Yugoslav council for the protection and improvement of environment - Kumrovec 1975; Eighth Yugoslav Symposium on Radiation Protection - Herceg Novi 975; Air protection from pollution and protection of cities from noise; Permanent Conference of Cities of
} 
Also, in 1970, the Institute of Criminological and Sociological Research did a study on "Environmental awareness and self-involvement of working people and citizens in protecting and improving the natural environment on the territory of Belgrade". The study was done at the request of the City Secretariat for Urbanism and Environment. [8] The study pointed out that the development of environmental initiatives and environmental awareness are socially very important issues. This research has shown that the development of environmental awareness and activities depends on the different social conditions, but also on the level of personality development. Some of these conditions favor the development of ecological activities and awareness, but there are conditions that slow down activities and environmental awareness such are elements of the chaotic development of the city, insufficiently resolved contradiction between directive and initiatives, the mismatch of formal and informal structures, lack of definition of responsibilities, ability to switch and to hide the responsibility, lack of ecological education, etc. [8]

Marković writes in his book Social Ecology, that Federal Constitution adopted in 1974 was the first constitution in the world that contained the new individual human right to a healthy environment:

Starting from the essence of socialist self-managing socio-economic relations and the position of man in socialist self-management, and also striving to affirm the principles of international documents on the national plan, primarily the United Nations Declaration about the Human environment in Yugoslavia, was established a constitutional human right to a healthy environment. [9]

Marković further quotes that this individual right of every man was based on the statement of the basic principles of the Constitution that a socialist society provides the conditions for the preservation and enhancement of natural and other values of environment that are of interest for a healthy, safe and effective life and work of present and future generations.[9] If we compare this definition with the definition of sustainable development from the Brundtland report from 1987 according to which sustainable development is defined as development that meets the needs of the present generation without compromising the future of the next generation, we can see the progressivity of the then environmental concerns.[10]

A number of authors wrote about the complexity of environmental problems in that time. In this context Simić believed that the environment is a unique system of the highest order, so that its protection cannot be achieved without a unified plan. The problem of environmental protection takes on the equally ecological, economic and social dimension. Consequently, environmental protection is an integral part of the planning process and one of the ultimate goals of the planning process in general. [11] So Stojkov in the journal Urbanism of Belgrade 59-60 from 1980 stated:

It is most often considered that environmental issues can and must be handled only by a team of specialists, while others only think about it marginally or not at all. Planning the improvement of the environment should be a means to synthesize a number of factors, and improvement of quality care for the environment should be an obligation of all participants in the planning process. Individual interests, solely

Yugoslavia - Sarajevo 1968; Legal aspects of environmental protection - Herceg Novi 1974; The first Congress of Ecologists of Yugoslavia - Belgrade in 1973. 
economic or technical fix approach, isolated aesthetic motives etc. should not be the reason for reduction the quality of the environment. But they often are. [12]

In the journal Urbanism of Belgrade no 31 from 1975 in text "Environmental Protection with urbanism" Stojanović emphasizes the difference between urbanism as a discipline of planning and the practice of urbanization in relation to the protection of the environment. Urbanization that is taking place as a result of various forces effects on the destruction or endangerment of the natural environment. In contrast urbanism represents science, expressed through planning practice and theory, which aims to harmonize the relationship between nature and the intervention envisaged by a plan. Urban plans should therefore protect nature and a man who is a part of this nature.

\section{IMPACT OF THE MEDia aS A FACTOR OF ECOLOGICAL AWARENESS DEVELOPMENT}

To show the level of development of ecological awareness in this period it is important to emphasize the presence of this issue in the media. Analyzing the informing the public as a factor of the development of environmental awareness in Belgrade Damjanović emphasizes that the press as a tool of mass information plays an important role in informing the public on environmental issues, with its particularly strong influence on shaping the public opinion about environmental issues. Thereby daily newspapers had a very important role, bearing in mind that at the end of the seventies of the twentieth century, the frequency of the texts with ecological content was growing. Thus, the newspaper "Večernje novosti" in 1978 doubled the number of environmental information in relation to the 1976 year. The other newspapers („Borba“, „Politika“ and „Politika ekspres") with minor deviations follow this tendency. Analysis of published information in relation to the presence of this topics shows that in the texts of four Belgrade newspapers was almost equally represented information whose "field of events" were Belgrade and Yugoslavia (43.0\%: 44.3\%), while information relating to other countries accounted for 13.0\%. [8]

Analysis of the frequency of topics indicates the different methods of Belgrade newspapers in influencing the development of environmental awareness. In fact, in the "Politika" was increasingly present orientation to the awakening of environmental awareness which is manifested in the most of information relating to the state of the environment and the processes of its degradation ( $82 \%$ of the articles compared to $18 \%$ of the articles relating to protection measures), while "Borba","Večernje novosti" and "Politika ekspres" developed their influence more on the information (about 3/4) relating to protective measures and improvement of environment.

But as Damjanovic concludes, all four newspapers had some common characteristics: 1) most of topics relating to the situation and problems of the urban area of Belgrade; 2) activities that relate to the environmental quality of the dwelling place, communal hygiene, infrastructure, and problems of space for leisure and recreation, are dominant; 3 ) neglect of contents related to the issue of secondary raw materials and natural resources; and 4) a common feature of all four newspapers is that the most numerous information are those whose content relates to the Action Plan of measures of protection and improvement of the environment, while topics relating to legislation - the control and penalties, are insufficiently present. [8] 
Certainly, we conclude that in the 70 s and 80 s, the influence of the media played a very important role in the development of the environmental awareness in Serbia.

\section{The Idea of Sustainable Development in Historical Urban Development OF NEW BELGRADE}

Due to the more intensive global process of urbanization and industrialization, in the seventies of the twentieth century, the concept of sustainable development becomes topical. The roots of this idea can be identified earlier, in the concepts that preceded to it: the concept of "green philosophy", "eco philosophy, "organic urbanism" and other concepts based on ecological approach to design and planning. In the field of architecture and urbanism a number of approaches and ideas was developed, but it can be noted that very often, advocates of urban sustainability rely on the previous work of visionaries of planning such are Patrick Geddes, Ebenezer Howard, Lewis Mumford and Jane Jacobs. [13] So also in the process of urbanization of New Belgrade we can recognize the reference to certain urban planning models of these predecessors of urban sustainability. Through these examples we can observe the positive and negative aspects of in the urban development of New Belgrade from the perspective of socio-ecological exchange.

Certainly that among the projects of the $20^{\text {th }}$ century that can be linked with the concept of sustainability are ideas of Le Corbusier who tried to make a sustainable connection between the nature in which is a city and the city itself. The backbone of Corbusier's concept of a functional city are high free-standing structures, which allow very high population densities, and which are at the same time surrounded by parks and vast green areas. [14] Is important to note that New Belgrade was designed according to the principles of the Athens Charter and modern urbanism. Until the transition period in nineties New Belgrade was the entirely mono-functional space designed for social housing. When we talk about the ambience of the modern city on the example of planning and construction of New Belgrade, we can see the obvious tendency to create a new society oriented towards a more humane environment. The ideology of modern movement in New Belgrade development was promoted through the vision of a new, clean and healthy city and application of new modern technologies. [10] The basic structural model of the New Belgrade functional city concept was reflected in open blocks surrounded by greenery and rejection of the classic street model that ,generates noise, dust and harmful gasses“.

Although conceived upon the ecological principles, modernist ideas provoked numerous criticisms as early as 1960's, which were primarily directed towards zoning, which inevitably resulted in the breakdown of integrated and poly-functional communities into mono-functional zones. [15] Also, the Charter of Machu-Picchu from 1977 criticized the principles of the Athens Charter, and insisted on "planning methods that have been directed towards the division of the city into its functional parts..." [16] and emphasized the importance of "establishing the integration of these parts" [16], which means that "the development of cities should not be encouraged in the direction of the division of the city into functional sectors, but on the contrary should be encouraged by multifunction integration" [16]. Leon Krier, also criticized the modernist urbanism, and claimed that the monofunctional zoning is "anti-ecological", because it leads to unnecessary consumption of time, energy and land. This situation Krier opposed to 
"good town" (by its nature ecological) in which the "totality of urban functions" is enabled, compatible and pleasant for walking distances". [17] In the critical text from 1964 "The City with which I disagree", architect Andrija Mutnjaković pointed out that the standard urbanism in the form of a "big grid" in which are placed isolated residential or public functions is not in line with the discourse of contemporary urbanism. From the viewpoint of sustainability, in the Yugoslav expert public can be of interest, a critical project "Biocity for Belgrade" conceived in 1965 in the competition for the urban design of residential complex for 30000 residents in New Belgrade. This project is the work of architect Andrija Mutnjiković. In the mentioned project, Mutnjaković proposes that the city should be created as an organism of mutually "interrelated" spaces with a free composition organically integrated into the landscape, while through the theory of biourbanism he researches the possibility of organizing the city as a "bio-logical urban unit". The project is based on the ideas of naturalness, open and spontaneous growth, as well as the attempt to overcome the alienation in the modern urban space. [18] Mutnjaković concept of biourbanism, at a time when it was created, was not able to achieve the implementation of the theoretical system in the reality of the construction industry and housing construction practices. However, today is possible to recognize the similarity of Mutnjaković's critical theory of biourbanism with thought of the leading Danish architectural practice BIG (Bjarke Ingels Group) and their project from year 2009 Zira Zero Island for Azerbaijan. This project is a combination of high-end housing and low-end use of resources and represents the future of sustainable urban development.

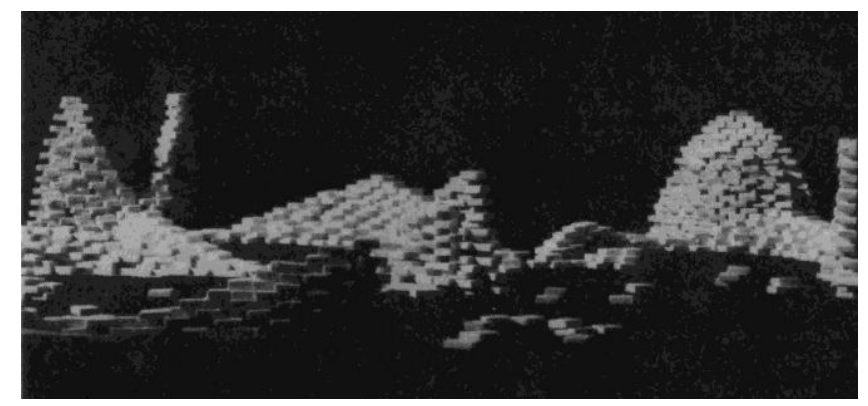

Fig. 1 Competition project „Biocity for Belgrade“, New Belgrade, 1965, Andrija Mutnjaković

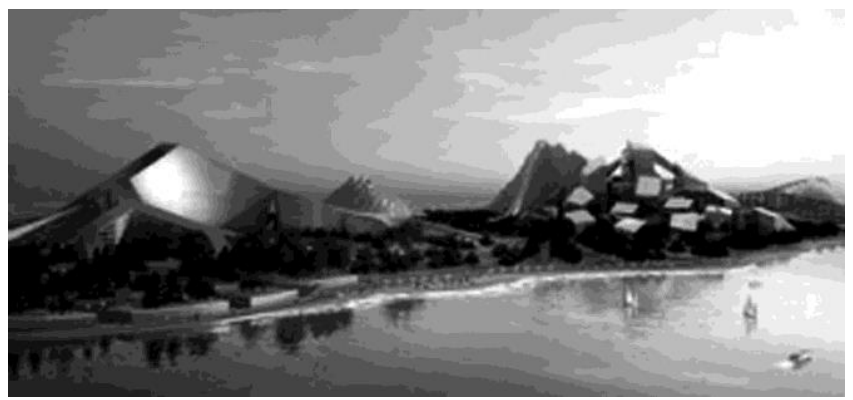

Fig. 2 Project ,, Zira Zero Island “, Azerbaijan, 2009, BIG 
From 1979 to 1984 Miloš Perović expressed the criticism against modern urbanism and the possibility of urban revival of New Belgrade in his two research studies, referring to the development of traditional neighborhood. Perović pointed out that the once set objectives for the development of central activities in New Belgrade should not remain as permanent values, but should depend on the functioning of social, economic and cultural development, so the urban structure of New Belgrade should not be the final outcome, but only a part of the continuous and sustainable planning process. [19] The crucial question relating to the future development of a modern city was raised at the Competition for urban structure improvement of New Belgrade in 1986. Among the submitted papers there was one of special importance, the criticism of a functional city by the Henry Lefebvre team where, through interdisciplinary approach, the new idea of ,right to the city“ [20] was presented.

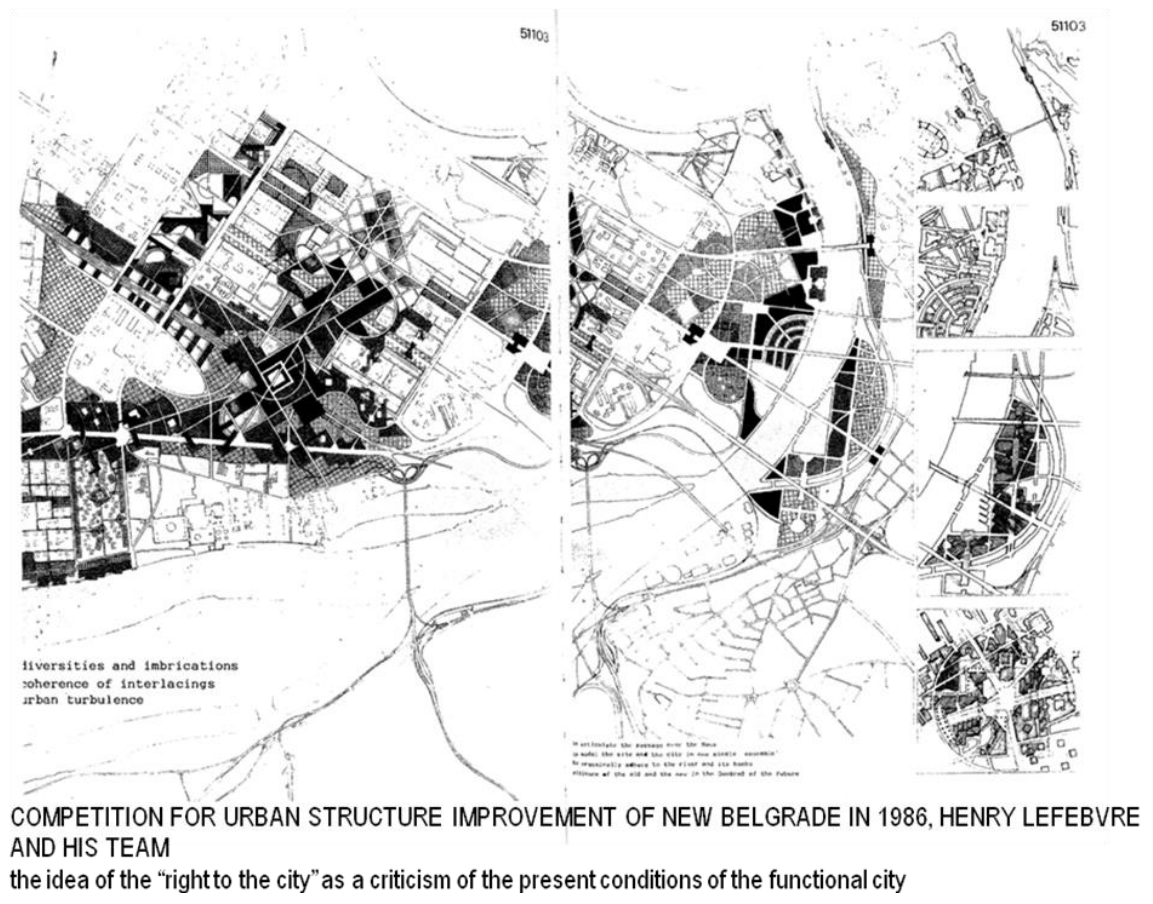

Fig. 3 Competition for urban structure improvement of New Belgrade, New Belgrade, 1986, Henri Lefebvre

After the 2000s New Belgrade undergoes the process of a contemporary re-urbanization in the post-socialist transition conditions that characterizes a part of space production in the global urban society. [21] Such changes have had a significant impact on the very structure of the users and quality of life in New Belgrade, particularly in terms of the complementarity of functions that enables sustainable transport and the reduction of the space-time fragmentation of the human needs (accommodation, work, free time). Owing to this, the former space of New Belgrade that was divided into zones and functional wholes is now given a more complex and more integrative structure, thus proving the sustainability of the modern city open plan. 


\section{CONCLUSIONS}

For the effective protection and promotion of human environment aside from adopting and implementing of legal regulations, is required relatively developed environmental awareness, which is based on the knowledge about the causes and manifestations of the ecological crisis and moral principles as a basis for developing responsibility and respect for the "environmental regulations". Through the study of the development of the place of ecology and environmental awareness in the process of urbanization of Belgrade in socialism, we can conclude that the ecology attitudes and ideas during that period were progressive, and that they followed a European initiative. Also, through the media not only the experts' environmental awareness was developed, but also of the rest of the public during this period.

By analyzing specific ideas and urban areas we can conclude that many principles of protecting and preserving the environment were implemented to a greater or lesser extent in the urban development of New Belgrade until the nineties of the twentieth century, and, which now belong to the principles of sustainable development. To overcome the negative effects of urbanization and planning the future political and ecological urban strategy, it is necessary to look at the historical development of environmental thought from the standpoint of the contemporary environmental strategies and thinking about the nature and the city.

Acknowledgement. The paper is a part of the research done within the projects TR36034 and OI179048 funded by the Ministry of Education, Science and Technological Development of the Republic of Serbia.

\section{REFERENCES}

1. Lj. Pušić, „Održivi grad: ka jednoj sociologiji okruženja“ [Sustainable city: towards a sociology of environment], Beograd: Nova175, 2001, str. 99.

2. F. Engels, Dialectics of Nature, New York: International Publishers, 1940

3. D. Harvey, Justice, Nature and the Geography of Difference, Oxford: Blackwell, 1996, p.88.

4. G. Keller, „Socijalizam i ekologija“[Socialism and ecology], in Čovjek i prostor (Zagreb) бр. 243, стр. 24., 1973

5. J. Kelcey, „Planiranje i ekologija u novom gradu” [Prevod: "Planing and ecology in a new town“, The planner, Vol. 62. (1976)], in Informacije, dokumentacija - program za pridružene članove. Beograd: Jugoslovenski institut za urbanizam i stanovanje, br. 76, 1976

6. S. Nikolić i M. Janić, Eds., „Ekološki aspekti planiranja privrednog razvoja“[Environmental aspects of development planning], in Horizonti urbanizma, informacije - program za pridružene članove, Beograd: Jugoslovenski institut za urbanizam i stanovanje, br. 3, 1976

7. M. Janković, Razvoj ekološke misli [The development of environmental thought], Beograd: EKO Centar, 1995, str. 8

8. Đ. Đurović, Ekološka svest i samoupravno angažovanje radnih ljudi i građana u zaštiti i unapređenju prirodne sredine na teritoriji Beograda [Environmental awareness and self-involvement of working people and citizens in protecting and improving the natural environment on the territory of Belgrade], Urbanizam Beograda br. 59, 60, Beograd, str. 17, 1980.

9. D. Marković, Socijalna ekologija [Social ecology], Beograd: Zavod za udžbenike i nastavna sredstva, 1986, str. 133.

10. J. Ristić Trajković, D. Stojiljković, and V. Krstić, "Influence of the socialist ideology on the conception of multi-family housing: new urban landscape and the typological models of housing units", Facta universitatis series: Architecture and Civil Engineering, vol. 13, no. 2, pp. 167-179, 2015., DOI: 10.2298/FUACE1502167R 
11. LJ. Simić, „Problem zaštite i životne sredine u okviru programa privredne stabilizacije“ [The problem of the protection and environment in the framework of the program of economic stabilization], in Urbanizam Beograda, br. 63-65, 1981.

12. B. Stojkov, „Faktori životne sredine kao kriterijumi za izbor lokacija za stanovanje“ [Environmental factors that the criteria for selecting of locations for housing], in Urbanizam Beograda br. 59, 60, 1980.

13. S. Viler, „Planiranje održivih prikladnih gradova“[Planning appropriate sustainable cities], in P Vujović, Urbana sociologija, Beograd: Zavod za udžbenike i nastavna sredstva, 2005, str. 295.

14. F. Šoe, Urbanizam, utopija i stvarnost [Urbanism, Utopia and Reality], Beograd: Gradevinska knjiga, 1978.

15. L. Krier, The Architecture of Community, Washington: Island Press, 2009.

16. Group of authors, Povelja "Maču Piču" [The Charter of Machu Picchu], Beograd: Arhitektonski fakultet, 1979 , str. 9,15 .

17. D Harvey, The Condition of Postmodernity, Oxford: Blackwell, 1990, p.67.

18. A. Mutnjaković, Biourbanizam [Biourbanism], Rijeka: Izdavački centar Rijeka, 1982, p. 140.

19. M. Perović, Iskustva prošlosti [Lessons of the Past], Beograd: Građevinska knjiga, 1985.

20. S. Bitter and H. Weber, Eds., Autogestion, or Henri Lefebvre in New Belgrade, Vienna: Grita Insam Gallery, 2009.

21. Lj. Blagojević, "Pejzaž slobodnog tržišta" [Landscape of the free market], Forum, no.53, pp. 58-59, 2008.

\section{ODRŽIVOST I SOCIJALIZAM: SOCIO-EKOLOŠKE IDEJE U URBANIZACIJI NOVOG BEOGRADA}

Ovaj rad ima za cilj da istraži ekološke ideje koji se pojavljuju u socijalističkom periodu, ili preciznije socio-ekološke ideje koje su bile prisutne u urbanizaciji Novog Beograda. Rad istražuje početak razvoja ekološke svesti koja se javlja krajem šezdesetih godina XX veka usled naglog procese urbanizacije Beograda, ali takođe ukazuje i na određene arhitektonske $i$ urbanističke koncepte u istorijskom razvoju Novog Beograda koji sa stanovišta savremenih principa održivosti predstavljaju pozitivne primere društveno-ekološke razmene. Šta možemo naučiti iz prethodnih iskustava? Budući da se odnosi moći društveno-ekoloških odnosa koji oblikuju urbane sredine stalno menjaju u pogledu razmere $i$ učesnika u procesu urbanizacije, istorijsko-geografski uvid u te stalno promenljive urbane konfiguracije neophodan je radi razumevanja i razmatranja buducih radikalnih političko-ekoloških urbanih strategija.

Ključne reči: ekologija, socijalizam, održivi urbani razvoj, društveno-ekološka razmena, Novi Beograd 